\title{
APLIKASI OPERASI HIMPUNAN DAN MATEMATIKA MORFOLOGI PADA PENGOLAHAN CITRA DIGITAL
}

\author{
V. Y. I. Ilwaru', Y. A. Lesnussa², E. M. Sahetapy ${ }^{3}$, Z. A. Leleury ${ }^{4}$ \\ 1,2,3,4 Jurusan Matematika FMIPA Universitas Pattimura \\ Jln. Ir. M. Putuhena, Kampus Unpatti, Poka-Ambon, Kode Pos 97233 \\ e-mail: 1'yopi_a_lesnussa@yahoo.com; ${ }^{2}$ zetharthur82@gmail.com
}

\begin{abstract}
Abstrak
Perkembangan teknologi pengolahan citra dewasa ini berkembang dengan sangat pesat, baik itu jumlah pemakai maupun jenis teknologi yang menggunakan pengolahan citra. Salah satu teknik pengolahan citra yang digunakan adalah deteksi tepi (edge detection). Pendeteksian tepi digunakan untuk meningkatkan penampakan garis batas suatu daerah atau obyek di dalam citra. Selain itu deteksi tepi digunakan untuk memperbaiki detail dari citra yang kabur, yang terjadi karena error atau adanya efek dari akuisisi citra. Pada penelitian ini dibahas pengolahan citra digital melibatkan operasi himpunan dan matematika morfologi dengan operasi yang digunakan yaitu Erosi, Dilasi, Opening, Closing, Internal Boundary, External Boundary, Morfologi Gradien, dan Filtering. Kemudian menerapkan setiap operasi dimaksud dalam mengolah image sehingga diperoleh hasil citra image dari setiap operasi himpunan dan matematika morfologi.
\end{abstract}

Kata Kunci : Matematika morfologi, operasi himpunan, pengolahan citra digital.

\section{APPLICATION OF SET OPERATIONS AND MATHEMATIC MORPHOLOGY ON DIGITAL IMAGE PROCESSING}

\begin{abstract}
The development of image processing technologies today are growing very rapidly, either the development number of users or the development kind of technology that uses image processing. There are many benefits in image processing. One of the image processing techniques used are edge detection. Edge detection is used to improve the appearance of boundary lines of an area or object in the image. Besides that edge detection is used to improve the detail of a blurred image, which occurs due to an error or the effect of image acquisition. Digital image processing involves the set operation sand the mathematical morphology that has been learned. Operations were used that erosion, dilation, Opening, Closing, Internal Boundary, External Boundary, Morphology Gradient, and Filtering.
\end{abstract}

Keywords: Digital image processing, mathematical morphology, set operations

\section{Pendahuluan}

Perkembangan teknologi pengolahan citra dewasa ini berkembang dengan sangat pesat, baik itu perkembangan jumlah pemakai maupun perkembangan jenis teknologi yang menggunakan pengolahan citra, misalnya bidang biomedis, astronomi, penginderaan jauh, dan arkeologi yang umumnya banyak memerlukan teknik peningkatan mutu citra. Aplikasi lain yang kemudian menyusul adalah pengolahan citra digital di bidang robotika, industri, serta arsip citra dan dokumen. Umumnya citra digital berbentuk persegi panjang atau bujur sangkar (pada beberapa sistem pencitraan ada pula yang berbentuk segi enam) yang memiliki lebar dan tinggi tertentu. Ukuran ini biasanya dinyatakan dalam banyaknya titik atau piksel sehingga ukuran citra selalu bernilai bulat. Setiap titik juga memiliki nilai berupa angka digital yang merepresentasikan informasi yang diwakili oleh titik tersebut. 
Ada banyak manfaat dalam pengolahan citra antara lain pengolahan citra dalam dunia komunikasi yaitu digunakan untuk memperjelas foto permukaan bumi yang dihasilkan dari satelit cuaca atau memperjelas foto planet-planet yang dihasilkan satelit penyidik, pengolahan citra dalam dunia fotografi digunakan sebagai pengganti kamera filter untuk membuat film hitam putih, efek berkabut, memberikan efek cahaya pada bagian tertentu pada foto, dll. Pengolahan citra dalam dunia kedokteran digunakan untuk memperjelas foto hasil X-ray organ tubuh manusia, hasil CT scan, dan lain-lain. Manfaat lainnya pengolahan citra digital dalam pengenalan pola yaitu pengenalan pola huruf, pola wajah, pola sidik jari, pola iris mata, dan sebagainya, juga pengolahan citra digital digunakan untuk keamanan data dan proteksi hak cipta.

Salah satu teknik pengolahan citra yang digunakan adalah deteksi tepi (edge detection). Pendeteksian tepi digunakan untuk meningkatkan penampakan garis batas suatu daerah atau olbyek di dalam citra. Selain itu deteksi tepi digunakan untuk memperbaiki detail dari citra yang kabur, yang terjadi karena error atau adanya efek dari akuisisi citra. Citra dari sudut pandang matematis, merupakan fungsi kontinu dari intensitas cahaya pada bidang dua dimensi $f(x, y)$, dengan $x$ dan $y$ adalah koordinat spasial dan amplitudo $f$ pada pasangan koordinat $(x, y)$ yang disebut intensitas atau derajat keabuan citra pada titik tersebut. Jika $x, y$, dan $f$ semuanya berhingga, dan nilainya diskrit, citra tersebut merupakan citra digital. Pengolahan citra digital melibatkan operasi himpunan dan matematika morfologi yang telah dipelajari. Morfologi matematika adalah teori yang sangat penting, dimana operasi tersebut harus didefinisikan oleh himpunan aritmatika. Morfologi matematika terdiri oleh serangkaian morfologi operator aljabar aritmatika. Dalam penelitian ini akan membahas tentang "Penerapan Operasi Himpunan dan Matematika Morfologi Pada Pengolahan Citra Digital”.

\section{Tinjauan Pustaka}

Citra adalah sinyal diskrit dua dimensi. Secara matematis, sinyal ini dapat direpresentasikan sebagai fungsi dari variabel-variabel dua dimensi. Setiap elemen dari array tersebut disebut piksel [1]. Suatu fungsi dua dimensi, dimana harga-harga fungsi tersebut $f(x, y)$ pada koordinat spasial $(x, y)$ di bidang $x$ dan $y$ mendefinisikan suatu ukuran intensitas cahaya atau kecermelangan titik tersebut [2]. Sedangkan menurut Foley [3], citra adalah array dari nilai-nilai dimana sebuah nilai tersebut adalah sekumpulan angka yang mendeskripsikan atribut dari piksel di dalamnya. Ada dua macam citra, yaitu citra diam dan citra bergerak. Citra diam merupakan citra tunggal yang tidak bergerak tetap, biasa disebut citra. Sedangkan citra bergerak merupakan rangkaian citra diam yang ditampilkan secara beruntun sehingga memberikan kesan pada mata sebagai gambar yang bergerak. Setiap citra di dalam rangkaian tersebut disebut frame.

Citra digital secara umum didefinisikan sebagai pemrosesan citra dua dimensi dengan komputer. Dalam definisi yang lebih luas, pengolahan cita digital juga mencakup semua data dua dimensi. Citra digital adalah barisan bilangan nyata maupun kompleks yang diwakili oleh bit-bit tertentu. Unit terkecil data digital adalah bit, yaitu angka biner, 0 dan 1. Kumpulan dari data sejumlah 8 bit data adalah sebuah unit data yang disebut byte, dengan nilai dari 0 - 225. Selanjutnya, Shih [4] dalam bukunya yang berjudul Image Processing and Mathematical Morphology membahas tentang bentuk-bentuk operasi yang melibatkan operasi himpunan dan logika matematika pada pengolahan citra digital meliputi dilasi dan erosi biner, serta operasi opening dan closing biner.

\section{Metodologi Penelitian}

Tipe penelitian adalah studi pustaka, yaitu mempelajari beberapa literatur yang berhubungan dengan penelitian kemudian mencoba membahas inti permasalahan tersebut dengan menuangkannya secara benar. Bahan atau materi yang digunakan dalam penelitian ini berupa karya ilmiah para matematikawan yang disajikan dalam bentuk pdf, buku cetak dan informasi ilmiah lainnya yang diperoleh dari materi-materi kuliah maupun media elektronik seperti internet. 


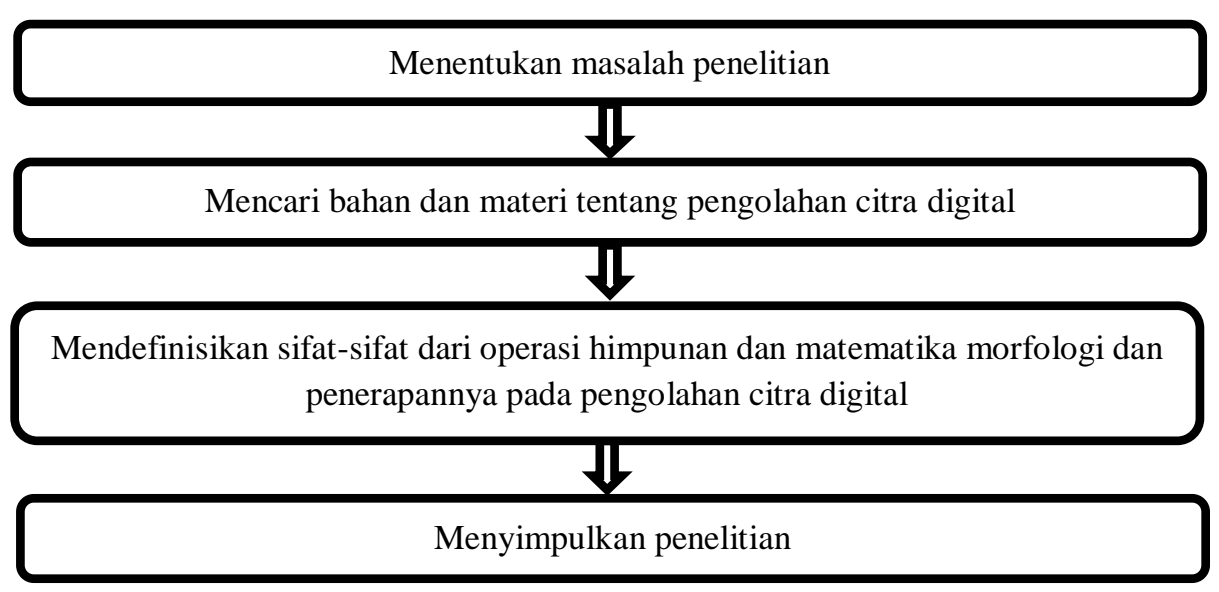

Gambar 1. Prosedur Penelitian

\section{Hasil dan Pembahasan}

\subsection{Operasi Himpunan Pada Citra Biner}

Dalam matematika morfologi, citra biner didefinisikan sebagai himpunan vektor (koordinat) dalam ruang Euclid $E^{N}$ : komposisi dari hitam dan putih dalam $N$-dimensi. $E^{N}$ menunjukkan himpunan semua titik $p=\left(x_{1}, x_{2}, \cdots, x_{N}\right)$ di ruang Euclid berdimensi $N$. Setiap himpunan $A$ sesuai dengan citra biner; yaitu dimensi $N$ dalam warna hitam dan putih, dimana titik $p$ adalah hitam pada gambar jika dan hanya jika $p \in$ $A$; sebaliknya, $p$ adalah putih. Sebuah citra biner dalam $E^{2}$ adalah siluet, satu himpunan mewakili daerah foreground (atau piksel hitam). Sebuah citra biner dalam $E^{3}$ adalah solid, satu himpunan mewakili permukaan dan interior benda. Citra biner berkorelasi dengan piksel hitam dan putih untuk sistem koordinat cartesius untuk citra biner.

Misalkan $A$ menunjukkan suatu himpunan (atau citra biner) di $E^{2}$. Jika himpunan tidak mengandung unsur-unsur, itu disebut himpunan kosong atau himpunan nol, dinotasikan $\emptyset$. Misalkan $a \in A$ menunjukkan elemen $a=\left(a_{1}, a_{2}\right)$ di $A$.

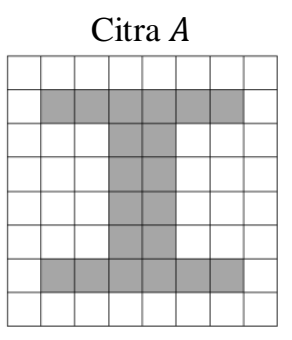

Citra $A^{c}$

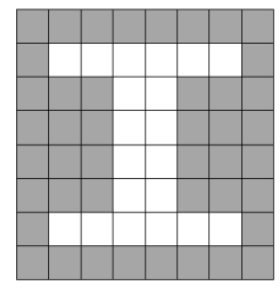

Gambar 2. Komplemen (atau terbalik) dari citra $A$

$$
\bar{A}=(\boldsymbol{A})^{c}=\{\boldsymbol{a} \mid \boldsymbol{a} \notin \boldsymbol{A}\}
$$

Citra A

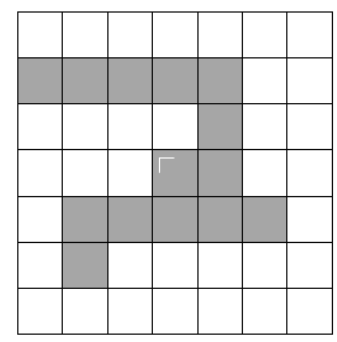

Citra $\hat{A}$

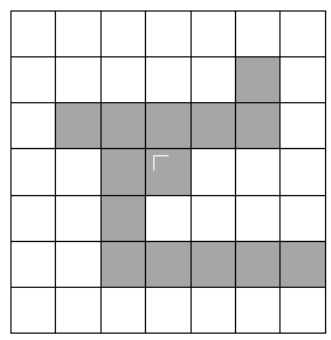

Gambar 3. Refleksi citra $A$ terhadap titik asal, identik dengan rotasi citra $A$ terhadap titik asal sebesar $180^{\circ}$

$$
\widehat{A}=\{\boldsymbol{b} \mid \boldsymbol{b}=-\boldsymbol{a}, \boldsymbol{a} \in \boldsymbol{A}\}
$$



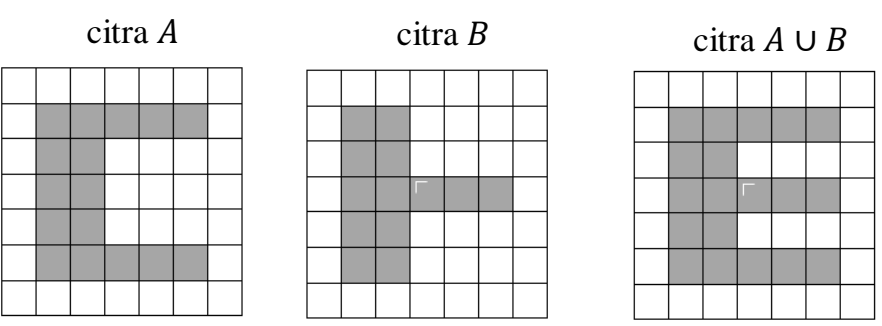

Gambar 4. Gabungan (union) citra $A$ dan $B$ $\boldsymbol{A} \cup \boldsymbol{B}=\{\boldsymbol{c} \mid \boldsymbol{c} \in \boldsymbol{A}$ atau $\boldsymbol{c} \in \boldsymbol{B}\}$

$\operatorname{citra} A$

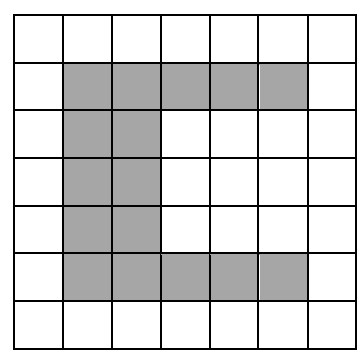

citra $B$

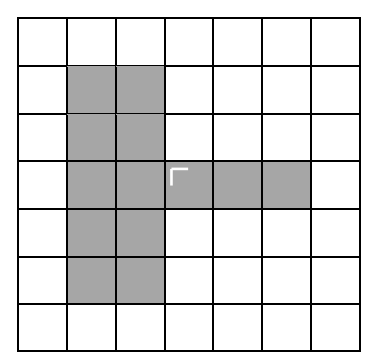

citra $A \cap B$

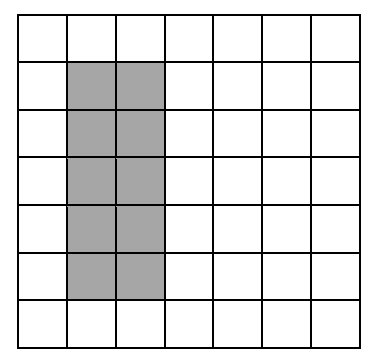

Gambar 5. Irisan (intersection) citra $A$ dan $B$ $A \cap B=\{c \mid c \in A$ dan $c \in B\}$

citra $A$

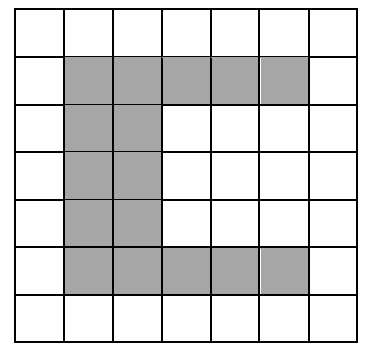

citra $B$

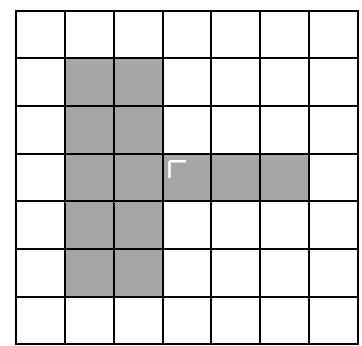

citra $A-B$

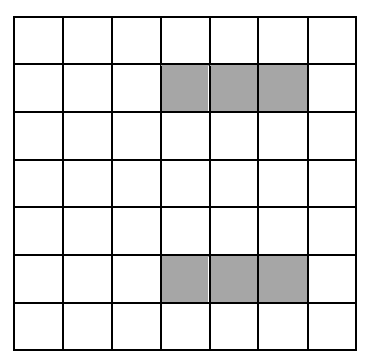

Gambar 6. Selisih citra $A$ oleh $B$

$$
A-B=A \backslash B=\{c \mid c \in A \text { dan } c \notin B\}=A \cap B^{c}
$$

\subsection{Translasi, Dilasi dan Erosi Biner}

Definisi 1. Misal $A \subset E^{N}$ dan $b \in E^{N}$. Tranlasi $A$ oleh $b$, ditulis $(A)_{b}$ adalah

$$
(A)_{b}=\left\{c \in E^{N} \mid c=a+b, \quad a \in A\right\} .
$$

Contoh 1. $A=\{(0,2),(1,1),(1,2),(2,0),(2,2),(3,1)\}, b=(0,1),(A)_{b}=\{(0,3),(1,2),(1,3),(2,1),(2,3),(3,2)\}$ 


\begin{tabular}{l|l|l|l|l|}
\multicolumn{1}{c}{} & \multicolumn{1}{c}{0} & 1 & 2 & 3 \\
\cline { 2 - 5 } 0 & 0 & 0 & 1 & 0 \\
\cline { 2 - 5 } 1 & 0 & 1 & 1 & 0 \\
\cline { 2 - 5 } 2 & 1 & 0 & 1 & 0 \\
\cline { 2 - 5 } 3 & 0 & 1 & 0 & 0 \\
\hline & \multicolumn{4}{c}{$A$}
\end{tabular}

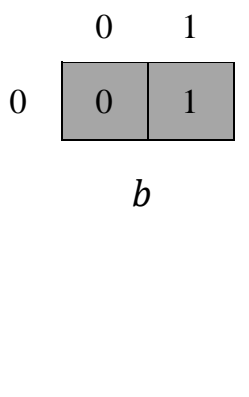

\begin{tabular}{l|l|l|l|l|}
\multicolumn{1}{c}{} & \multicolumn{1}{c}{0} & 1 & 2 & 3 \\
\cline { 2 - 5 } 0 & 0 & 0 & 0 & 1 \\
\cline { 2 - 5 } 1 & 0 & 0 & 1 & 1 \\
\cline { 2 - 5 } 2 & 0 & 1 & 0 & 1 \\
\cline { 2 - 5 } 3 & 0 & 0 & 1 & 0 \\
\cline { 2 - 5 } & & \multicolumn{3}{c}{$(A)$}
\end{tabular}

$(A)_{b}$

Definisi 2. Misal $A, B \subset E^{N}$. Dilasi biner dari $A \operatorname{oleh} B$, ditulis $A \oplus_{b} B$ adalah $A \oplus_{b} B=\left\{c \in E^{N} \mid c=a+b, a \in A, b \in B\right\}$

(Indeks $b$ menyatakan biner)

Perhatikan bahwa

\section{Contoh 2.}

$$
A \oplus_{b} B=\bigcup_{b \in B}(A)_{b}=\bigcup_{a \in A}(B)_{a}
$$
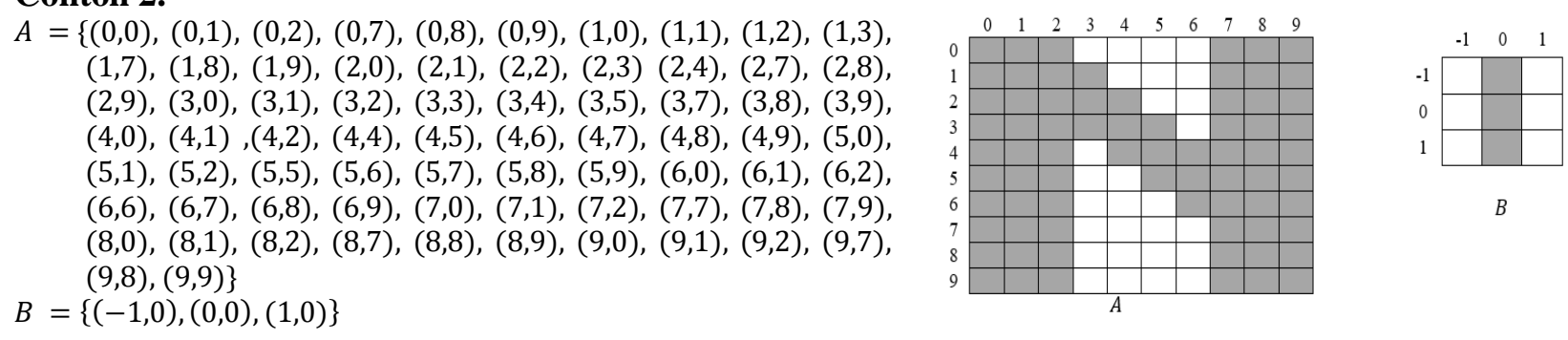

$B$

$A \oplus_{b} B=\{(-1,0),(0,0),(1,0),(-1,1),(0,1),(1,1),(-1,2),(0,2)$, $(1,2),(-1,7),(0,7),(1,7),(-1,8),(0,8),(1,8),(-1,9)$, $(0,9),(1,9),(2,0),(2,1),(2,2),(0,3),(1,3),(2,3)$, $(2,8),(2,9),(3,0),(3,1),(3,2),(3,3),(1,4),(2,4)$, $(3,4),(3,7),(3,8),(3,9),(4,0),(4,1),(4,2),(4,3)$, $(4,4),(2,5),(3,5),(4,5),(4,7),(4,8),(4,9),(5,0)$, $(5,1),(5,2),(5,4),(5,5),(3,6),(4,6),(5,6),(5,7)$, $(5,8),(5,9),(6,0),(6,1),(6,2),(6,5),(6,6),(6,7)$, $(6,8),(6,9),(7,0),(7,1),(7,2),(7,6),(7,7),(7,8)$, $(7,9),(8,0),(8,1),(8,2),(8,7),(8,8),(8,9),(9,0)$, $(9,1),(9,2),(9,7),(9,8),(9,9),(10,0),(10,1),(10,2)$,

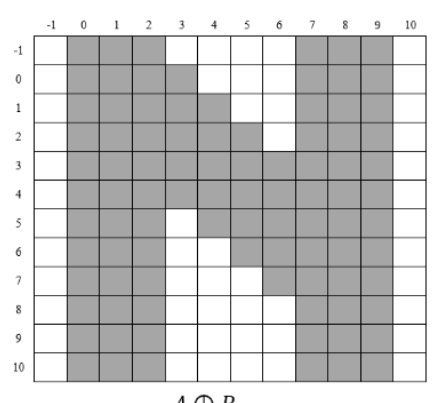
$(10,7),(10,8),(10,9)\}$

Definisi 3. Erosi biner dari $A$ oleh $B$, ditulis $A \ominus_{b} B$, adalah $A \Theta_{b} B=\left\{x \in E^{N} \mid x+b \in A\right.$ untuk $\left.b \in B\right\}$

Definisi di atas ekivalen dengan $A \ominus_{b} B=\bigcap_{b \in B}(A)_{-b}$

Erosi $A \ominus_{b} B$ dapat dipandang sebagai tempat kedudukan semua pusat c, sehingga translasi $(B)_{c}$ termuat di dalam himpunan $\mathrm{A}$

$$
A \ominus_{b} B=\left\{c \in E^{N} ;(B)_{c} \subseteq A\right\}
$$

\section{Contoh 3.}

$A=\{(0,0),(0,1),(0,2),(0,7),(0,8),(0,9),(1,0),(1,1),(1,2),(1,3),(1,7),(1,8),(1,9),(2,0),(2,1),(2,2),(2,4)$, $(2,7),(2,8),(2,9),(3,0),(3,1),(3,2),(3,3),(3,4),(3,5),(3,7),(3,8),(3,9),(4,0),(4,1),(4,2),(4,4),(4,5)$, $(4,6),(4,7),(4,8),(4,9),(5,0),(5,1),(5,2),(5,5),(5,6),(5,7),(5,8),(5,9),(6,0),(6,1),(6,2),(6,6),(6,7)$, 
$(6,8),(6,9),(7,0),(7,1),(7,2),(7,7),(7,8),(7,9),(8,0),(8,1),(8,2),(8,7),(8,8),(8,9),(9,0),(9,1),(9,2)$, $(9,7),(9,8),(9,9)\}$

$B=\{(-1,0),(0,-1),(0,0),(0,1),(1,0)\}$

$A \Theta_{b} B=\{(1,1),(1,2),(1,8),(2,1),(2,2),(2,3),(2,8),(3,1),(3,2),(3,4),(3,8),(4,1),(4,5),(4,7),(4,8),(4,9)$, $(5,0),(5,1),(5,6),(5,7),(5,8),(6,1),(6,7),(6,8),(7,1),(7,8),(8,1),(8,8)\}$
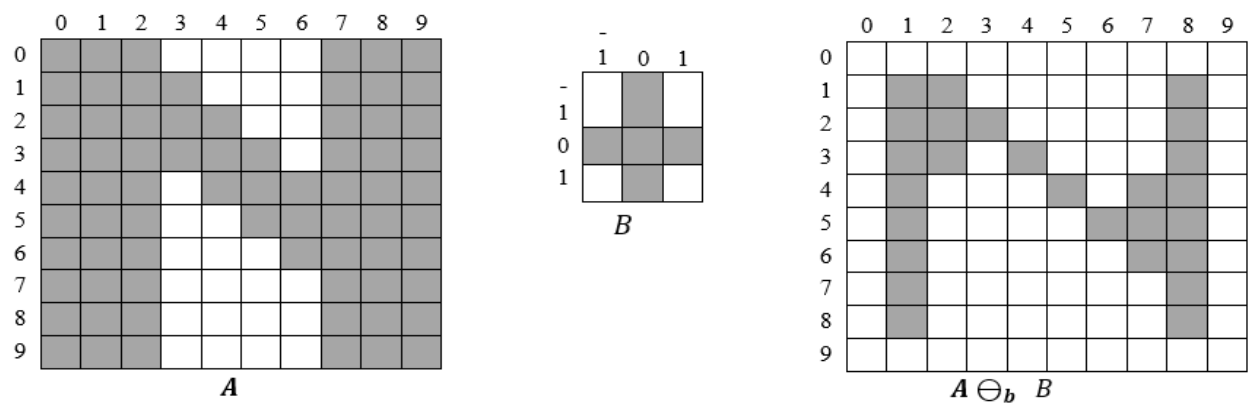

Apabila telah jelas dilasi dan erosi digunakan untuk citra biner A dan elemen pembentuk (structuring element) biner B, maka indeks $b$ dapat dihilangkan.
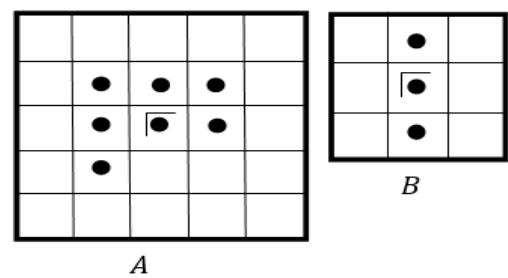

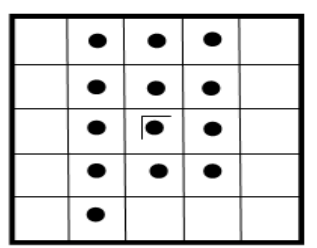

$A \oplus B$

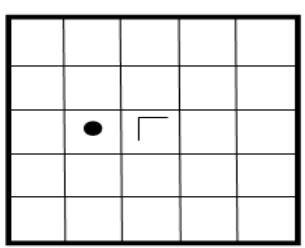

$A \ominus B$

\section{Gambar 7. Dilasi Biner dan Erosi Biner}

\subsection{Opening dan Closing}

Definisi 4. Opening pada suatu citra $A$ menggunakan elemen pembentuk $B$, ditulis

$A \circ B$, didefinisikan sebagai

$A \circ B=(A \ominus B) \oplus B$

Dengan operasi himpunan, opening dapat dipandang sebagai gabungan semua translasi dari B yang termuat di A:

$$
A \circ B=\bigcup_{B_{x} \subseteq A} B_{x}
$$

\section{Contoh 4.}

$A=\{(1,3),(1,4),(1,5),(1,6),(2,3),(2,4),(2,5),(2,6)$,

$(3,1),(3,2),(3,3),(3,4),(3,5),(3,6),(4,1),(4,2)$,

$(4,3),(4,4),(4,5),(4,6),(5,1),(5,2),(5,3),(5,4)$,

$(6,1),(6,2),(6,3),(6,4)\}$

$B=\{(-1,0),(0,-1),(0,0),(0,1),(1,0)\}$

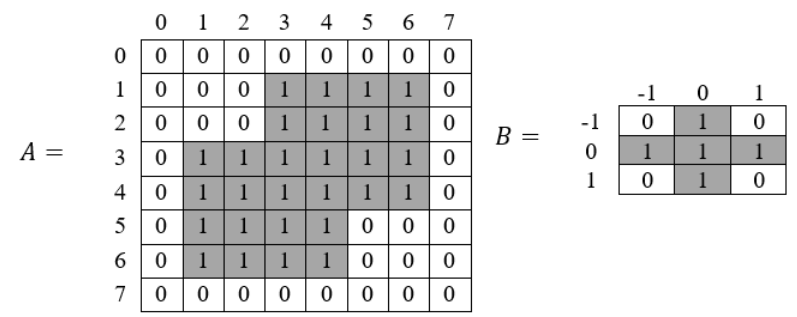

Untuk memperoleh opening $A$ o $B$ maka elemen pembentuk B digerakkan di dalam citra $A$ kemudian ditandai bagian yang dilalui. Opening dapat juga dipandang sebagai gabungan semua translasi dari $B$ yang termuat di $A$

$$
A \circ B=(A \ominus B) \oplus B
$$




\section{Contoh 5.}

$A=\{(1,3),(1,4),(1,5),(1,6),(2,3),(2,4),(2,5),(2,6)$, $(3,1),(3,2),(3,3),(3,4),(3,5),(3,6),(4,1),(4,2)$, $(4,3),(4,4),(4,5),(4,6),(5,1),(5,2),(5,3),(5,4)$, $(6,1),(6,2),(6,3),(6,4)\}$

$B=\{(-1,0),(0,-1),(0,0),(0,1),(1,0)\}$

$(A \ominus B)=\{(2,4,(2,5),(3,3),(3,4),(3,5),(4,2)$, $(4,3),(4,4),(5,2),(5,3)\}$

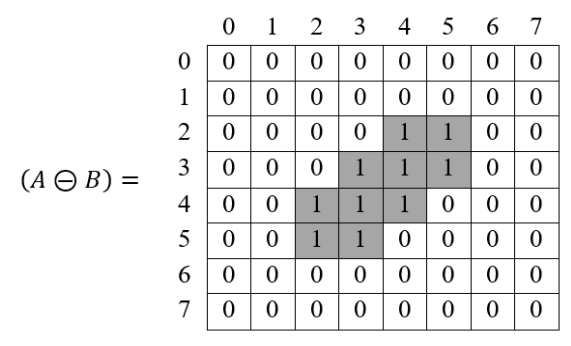

$(A \circ B)=\{(2,4),(2,5),(3,3),(3,4),(3,5),(4,2),(4,3),(4,4),(5,2),(5,3)\} \oplus$ $\{(-1,0),(0,-1),(0,0),(0,1),(1,0)\}$

$A \circ B=$

\begin{tabular}{|c|c|c|c|c|c|c|c|c|}
\hline & 0 & 1 & 2 & 3 & 4 & 5 & 6 & 7 \\
\hline 0 & 0 & 0 & 0 & 0 & 0 & 0 & 0 & 0 \\
\hline 1 & 0 & 0 & 0 & 0 & 0 & 0 & 0 & 0 \\
\hline 2 & 0 & 0 & 0 & 0 & 1 & 1 & 0 & 0 \\
\hline 3 & 0 & 0 & 0 & 1 & 1 & 1 & 0 & 0 \\
\hline 4 & 0 & 0 & 1 & 1 & 1 & 0 & 0 & 0 \\
\hline 5 & 0 & 0 & 1 & 1 & 0 & 0 & 0 & 0 \\
\hline 6 & 0 & 0 & 0 & 0 & 0 & 0 & 0 & 0 \\
\hline 7 & 0 & 0 & 0 & 0 & 0 & 0 & 0 & 0 \\
\hline
\end{tabular}

$\oplus$

\begin{tabular}{c|c|c|c|}
\multicolumn{1}{c}{} & \multicolumn{1}{c}{-1} & 0 & 1 \\
\hline \multirow{2}{*}{-1} & 0 & 1 & 0 \\
\cline { 2 - 4 } 0 & 1 & 1 & 1 \\
\hline & 0 & 1 & 0 \\
\cline { 2 - 4 } 1 & &
\end{tabular}

$(A \circ B)=\{(1,4), \quad(1,5),(2,3), \quad(2,4), \quad(2,5), \quad(3,2), \quad(3,3)$, $(3,4),(4,2),(4,3),(4,1),(5,1),(5,2),(3,5),(4,4)$, $(5,3),(2,6),(3,6),(4,5),(4,5),(5,4),(6,2),(6,3)\}$

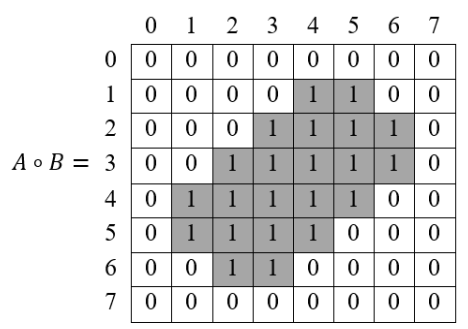

Definisi 5. Closing pada suatu citra $A$ menggunakan elemen pembentuk $B$, ditulis $A \bullet B$, didefinisikan sebagai

$$
A \bullet B=(A \oplus B) \ominus B
$$

Dengan operasi himpunan, closing dapat dipandang sebagai komplemen dari gabungan semua translasi B yang termuat di $A^{c}$ :

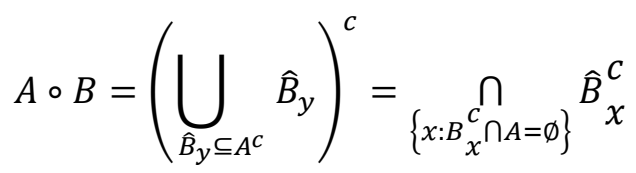

Contoh 6. Contoh yang digunakan sama dengan contoh di atas. Closing $A \bullet \mathrm{B}$ dapat dipandang sebagai komplemen dari gabungan semua translasi dari $B$ yang termuat di $A^{c} . A \oplus B$ adalah bagian yang dilalui ketika titik pusat $B$ digerakan pada citra $A$.

$$
A \bullet B=(A \oplus B) \ominus B
$$


$(A \oplus B)=\{(0,3),(0,4),(0,5),(0,6),(1,3),(1,4),(1,5)$, $(1,6),(2,1),(2,2),(2,3),(2,4),(2,5),(2,6)$, $(3,1),(3,2),(3,3),(3,4),(3,5),(3,6),(4,1)$, $(4,2),(4,3),(4,4),(5,1),(5,2),(5,3),(5,4)$, $(1,2),(3,0),(4,0),(4,5),(5,0),(6,0),(6,1)$, $(6,2),(6,3),(4,6),(6,4),(1,7),(2,7),(3,7)$, $(4,7),(5,5),(6,5),(5,6),(7,1),(7,2),(7,3)$, $(7,4)\}$

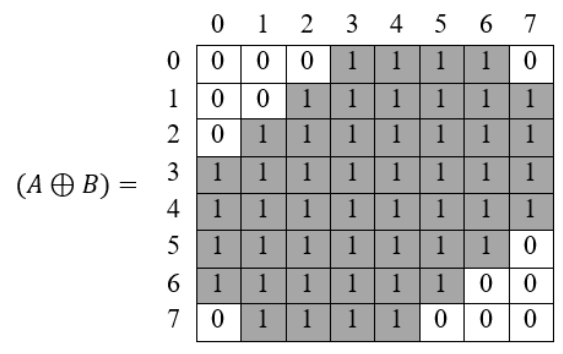

$A \bullet B=\{(0,3),(0,4),(0,5),(0,6),(1,3),(1,4),(1,5),(1,6),(2,1),(2,2),(2,3),(2,4),(2,5)$, $(2,6),(3,1),(3,2),(3,3),(3,4),(3,5),(3,6),(4,1),(4,2),(4,3),(4,4),(5,1),(5,2)$, $(5,3),(5,4),(1,2),(3,0),(4,0),(4,5),(5,0),(6,0),(6,1),(6,2),(6,3),(4,6),(6,4)$, $(1,7),(2,7),(3,7),(4,7),(5,5),(6,5),(5,6),(7,1),(7,2),(7,3),(7,4)\} \ominus$ $\{(-1,0),(0,-1),(0,0),(0,1),(1,0)\}$

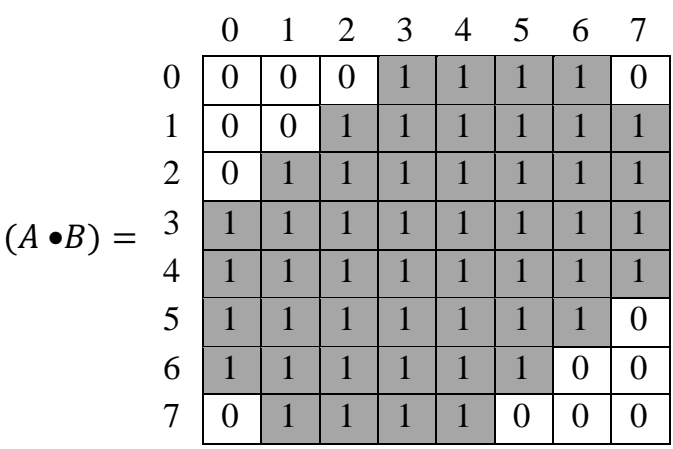

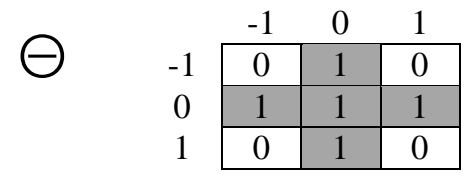

$A \bullet B=\{(1,3),(1,4),(1,5),(1,6),(2,2),(2,3),(2,4),(2,5),(2,6),(3,1),(3,2),(3,3),(3,4),(3,5),(3,6),(4,1),(4,2)$, $(4,3),(4,4),(4,5),(4,6),(5,1),(5,2),(5,3),(5,4),(5,5),(6,1),(6,2),(6,3),(6,4)\}$

\begin{tabular}{|c|c|c|c|c|c|c|c|c|}
\hline & 0 & 1 & 2 & 3 & 4 & 5 & 6 & 7 \\
\hline & $0 \longdiv { 0 }$ & 0 & 0 & 0 & 0 & 0 & \begin{tabular}{|l|l} 
\\
\end{tabular} & 0 \\
\hline & $1 \longdiv { 0 }$ & 0 & 0 & 1 & 1 & 1 & 1 & 0 \\
\hline & $2 \longdiv { 0 }$ & $\begin{array}{ll}0 \\
\end{array}$ & 1 & 1 & 1 & 1 & 1 & 0 \\
\hline & $3 \longdiv { 0 }$ & $\begin{array}{ll}0 \\
\end{array}$ & 1 & 1 & 1 & 1 & 1 & 0 \\
\hline i) & $4 \longdiv { 0 }$ & 1 & 1 & 1 & 1 & 1 & 1 & 0 \\
\hline & $5 \longdiv { 0 }$ & 1 & 1 & 1 & 1 & 1 & 0 & 0 \\
\hline & $6 \longdiv { 0 }$ & \begin{tabular}{l|l}
) & 1
\end{tabular} & 1 & 1 & 1 & 0 & 0 & 0 \\
\hline & $7 \longdiv { 0 }$ & $\begin{array}{l}0 \\
\end{array}$ & 0 & 0 & 0 & 0 & \begin{tabular}{|l|l|} 
\\
\end{tabular} & 0 \\
\hline
\end{tabular}

\subsection{Deteksi Bidang}

Salah satu aplikasi operasi erosi adalah untuk deteksi bidang batas suatu objek dalam citra. Jika A suatu citra dan B adalah suatu structuring element yang kecil yang terdiri atas titik yang diletakkan secara sistematis terhadap origin, maka dapat didefinisikan bidang batas A dengan beberapa metode sebagai berikut.
i. $\quad A-(A \Theta \mathrm{B})$ "internal boundary"
ii. ( $(\mathrm{A} \oplus \mathrm{B})-A)$ "external boundary"
iii. $(\mathrm{A} \oplus \mathrm{B})-(A \oplus \mathrm{B})$ "morphological gradient" 


\section{Contoh 7.}

$A=\{(0,2),(0,3),(1,1),(1,2),(1,3),(1,4),(2,0),(2,1),(2,2),(2,3),(2,4),(2,5),(3,0),(3,1),(3,2),(3,3),(3,4)$, $(3,5),(4,1),(4,2),(4,3),(4,4),(5,2),(5,3)\}$

$B=\{(-1,-1),(-1,1),(0,0),(1,-1),(1,1)\}$

$\mathrm{A} \oplus \mathrm{B}=\{(-1,1),(-1,3),(0,2),(1,1),(1,3),(-1,2),(-1,4),(0,3),(1,2),(1,4),(0,0),(2,0),(2,2),(0,1),(2,1)$, $(2,3),(2,4),(0,5),(2,5),(1,-1),(3,-1),(3,1),(1,0),(3,0),(3,2),(1,5),(3,3),(3,4),(2,4),(3,5),(4,-$ $1),(4,1),(4,0),(4,2),(4,3),(4,4),(2,3),(2,5),(4,5),(2,6),(3,5),(4,6),(5,0),(5,2),(5,1),(5,3)$, $(5,4),(5,5),(6,1),(6,3),(6,2),(6,4)\}$

$A \ominus B=\{(2,2),(2,3),(3,2),(3,3)\}$

$(\mathrm{A} \oplus \mathrm{B})-A=\{(-1,1),(-1,3),(-1,2),(-1,4),(0,0),(0,1),(0,4),(0,5),(1,-1),(3,-1),(1,0),(1,6),(3,6),(2,-1)$, $(4,-1),(4,0),(4,5),(2,6),(4,6),(5,0),(5,1),(5,4),(5,5),(6,1),(6,3),(6,2),(6,4)\}$

$A-(A \ominus B)=\{(0,2),(0,3),(1,1),(1,2),(1,3),(1,4),(2,0),(2,1),(2,4),(2,5),(3,0),(3,1),(3,4),(3,5),(4,1)$, $(4,2),(4,3),(4,4),(5,2),(5,3)\}$

$(\mathrm{A} \oplus \mathrm{B})-(A \ominus B)=\{(-1,1),(-1,3),(0,2),(1,1),(1,3),(-1,2),(-1,4),(0,3),(1,2),(1,4),(0,0),(2,0),(0,1)$, $(2,1),(0,4),(2,4),(0,5),(2,5),(1,-1),(3,-1),(3,1),(1,0),(3,0),(1,5),(1,6),(3,6),(2,-$ $1),(4,-1),(4,1),(4,0),(4,2),(4,3),(4,4),(2,5),(4,5),(2,6),(3,5),(4,6),(5,0),(5,2)$, $(5,1),(5,3),(5,4),(5,5),(6,1),(6,3),(6,2),(6,4)\}$

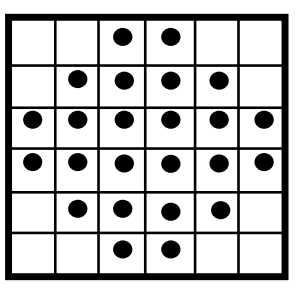

$A$

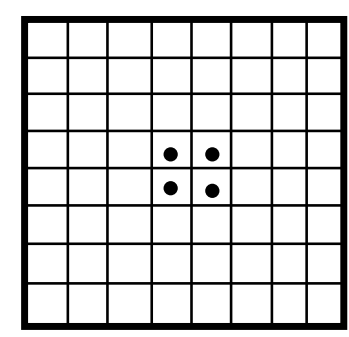

$A \ominus B$
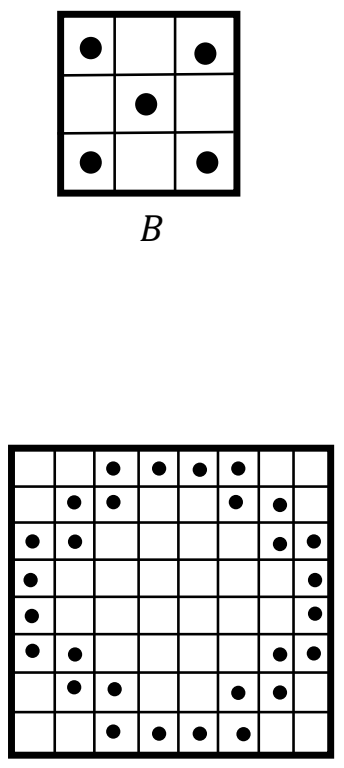

$(\mathrm{A} \oplus \mathrm{B})-A$

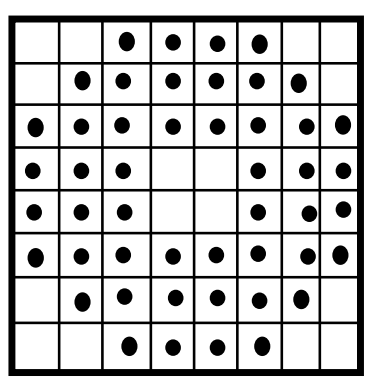

$(\mathrm{A} \oplus \mathrm{B})-(\mathrm{A} \ominus \mathrm{B})$

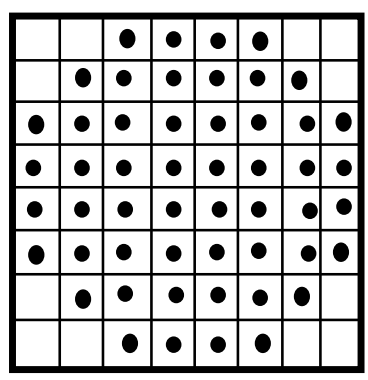

$(A \oplus B)$

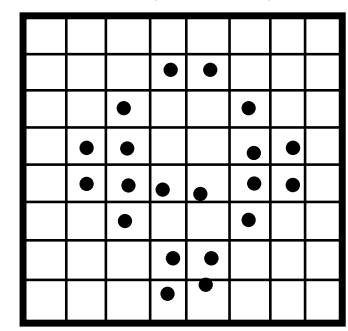

$A-(A \ominus B)$ 


\subsection{Filtering}

Misalkan terdapat citra biner $A$ yang terkena derau implus - piksel yang seharusnya hitam menjadi putih dan sebaliknya. Maka $(\mathrm{A} \ominus \mathrm{B})$ akan menghilangkan piksel hitam tunggal namun akan memperbesar lubang-lubang yang ada.Untuk menghilangkan lubang dapat dilakukan dilasi dua kali secara berurutan.

$$
((\boldsymbol{A} \ominus \boldsymbol{B}) \oplus \boldsymbol{B}) \oplus \boldsymbol{B}
$$

Dilasi yang pertama akan mengembalikan lubang-lubang ke ukuran semula dan operasi dilasi yang kedua akan menghilangkan lubang-lubang tersebut. Namun hal ini juga akan memperbesar objek pada citra. Untuk mengembalikan objek ke ukuran semula maka dapat dilakukan erosi, sehingga operasi secara keseluruhan dapat dinyatakan sebagai berikut.

$$
(((\boldsymbol{A} \ominus \mathbf{B}) \oplus \mathbf{B}) \oplus \mathbf{B}) \ominus \mathbf{B}
$$

Operasi tersebut juga dapat dinyatakan sebagai berikut

$$
(\boldsymbol{A} \circ \boldsymbol{B}) \bullet \boldsymbol{B}
$$

Operasi tersebut disebut morphological filtering.

\section{Contoh 8.}

$A=\{(0,1),(0,3),(0,4),(0,5),(0,6),(1,2),(1,3),(1,4),(1,5),(1,6),(1,7),(1,9),(2,1),(2,2),(2,3),(2,6),(2,7)$, $(2,8),(3,1),(3,2),(3,3),(3,6),(3,7),(3,8),(4,1),(4,2),(4,3),(4,6),(4,7),(4,8),(5,1),(5,2),(5,3),(5,6)$, $(5,7),(5,8),(5,10),(6,1),(6,2),(6,3),(6,6),(6,7),(6,8),(7,1),(7,2),(7,3),(7,6),(7,7),(7,8),(8,0),(8,2)$, $(8,3),(8,4),(8,5),(8,6),(8,7),(9,3),(9,4),(9,5),(9,6),(9,9),(10,1),(10,6),(10,9)\}$

$B=\{(0,0),(0,1)\}$

$A \ominus B=\{(0,3),(0,4),(0,5),(1,2),(1,3),(1,4),(1,5),(1,6),(2,1),(2,2),(2,6),(2,7),(3,1),(3,2),(3,6),(3,7)$, $(4,1),(4,2),(4,6),(4,7),(4,8),(5,1),(5,2),(5,3),(5,6),(5,7),(5,8),(5,10),(6,1),(6,2),(6,3),(6,6)$, $(6,7),(6,8),(7,1),(7,2),(7,6),(7,7),(7,8),(8,0),(8,2),(8,3),(8,4),(8,5),(8,6),(8,7),(9,3),(9,4)$, $(9,5)\}$

$(A \ominus B) \oplus B=\{(0,3),(0,4),(0,5),(0,6),(1,2),(1,3),(1,4),(1,5),(1,6),(1,7),(2,1),(2,2),(2,3),(2,6),(2,7)$, $(2,8),(3,1),(3,2),(3,3),(3,6),(3,7),(3,8),(4,1),(4,2),(4,3),(4,6),(4,7),(4,8),(5,1),(5,2)$, $(5,3),(5,6),(5,7),(5,8),(6,1),(6,2),(6,3),(6,6),(6,7),(6,8),(7,1),(7,2),(7,3),(7,6),(7,7)$, $(7,8),(8,2),(8,3),(8,4),(8,5),(8,6),(8,7),(9,3),(9,4),(9,5),(9,6)\}$

$((\boldsymbol{A} \ominus \boldsymbol{B}) \oplus \boldsymbol{B}) \oplus \boldsymbol{B}=\{(0,3),(0,4),(0,5),(0,6),(0,7),(1,2),(1,3),(1,4),(1,5),(1,6),(1,7),(1,8), \quad(2,1)$, $(2,2),(2,3),(2,4),(2,6),(2,7),(2,8),(2,9),(3,1),(3,2),(3,3),(3,4),(3,6),(3,7)$, $(3,8),(3,9),(4,1),(4,2),(4,3),(4,4),(4,6),(4,7),(4,8),(4,9),(5,1),(5,2),(5,3)$, $(5,4),(5,6),(5,7),(5,8),(5,9),(6,1),(6,2),(6,3),(6,4),(6,6),(6,7),(6,8),(6,9)$, (7,1), (7,2), (7,3), (7,4), (7,6), (7,7), (7,8), (7,9), (8,2), (8,3), (8,4), (8,5), (8,6), $(8,7),(8,8),(9,3),(9,4),(9,5),(9,6),(9,7)$,

$(((\boldsymbol{A} \ominus \boldsymbol{B}) \oplus \boldsymbol{B}) \oplus \boldsymbol{B}) \ominus \boldsymbol{B}=\{(0,3),(0,4),(0,5),(0,6),(1,2),(1,3),(1,4),(1,5),(1,6),(1,7),(2,1),(2,2)$, $(2,3),(2,6),(2,7),(2,8),(3,1),(3,2),(3,3),(3,6),(3,7),(3,8),(4,1),(4,2)$, $(4,3),(4,6),(4,7),(4,8),(5,1),(5,2),(5,3),(5,6),(5,7),(5,8),(6,1),(6,2)$, $(6,3),(6,6),(6,7),(6,8),(7,1),(7,2),(7,3),(7,6),(7,7),(7,8),(8,2),(8,3)$, $(8,4),(8,5),(8,6),(8,7),(9,3),(9,4),(9,5),(9,6)\}$ 
$\begin{array}{lllllllllll}0 & 1 & 2 & 3 & 4 & 5 & 6 & 7 & 8 & 9 & 10\end{array}$
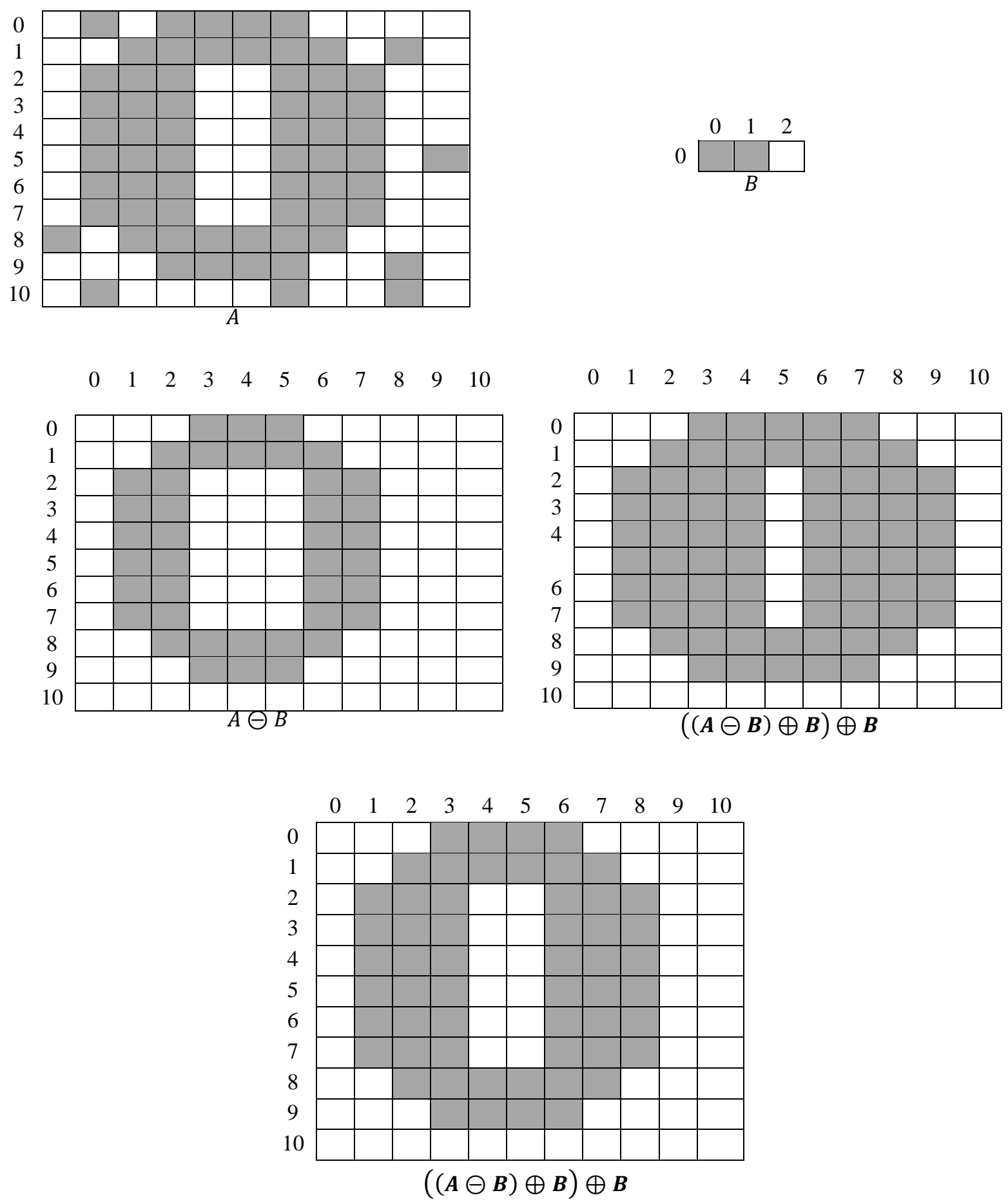

Dari gambar di atas dapat lihat, pada citra biner A terdapat derau yang seharusnya tidak ada pada citra tersebut. Untuk menghilangkan derau tersebut maka dilakukan erosi dengan menggunakan elemen pembentuk B. Setelah dilakukan erosi ternyata derau yang sebelumnya ada pada citra A hilang namun terjadi pengikisan pada objek. Untuk mengembalikan pada citra aslinya maka dilakukan dilasi dua kali secara berurutan. Namun dengan dilakukan dilasi dua kali terjadi penebalan pada objek, sehingga untuk mengembalikan objek ke ukuran semula maka dilakukan erosi. Setelah dilakukan erosi maka objek kembali ke bentuk aslinya. 


\subsection{Simulasi Dengan MATLAB}

Berikut adalah contoh listing program untuk Erosi, Dilasi, Opening Closing, Exsternal Boundary, Internal Boundary, dan Morfologi Gradien, dengan citra A yaitu "Matematika Morfologi". Output yang dihasilkan adalah sebagai berikut.

A.

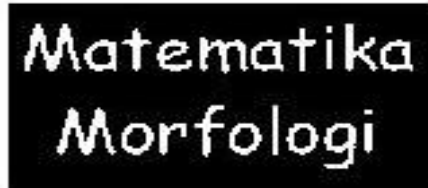

Opening

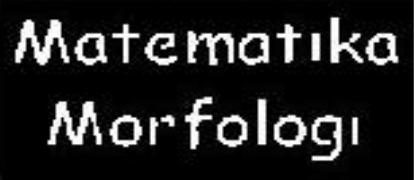

eksternal boundary

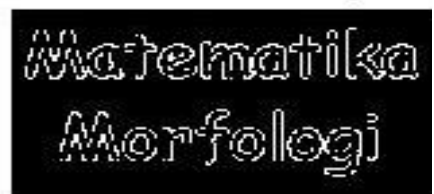

Erosi

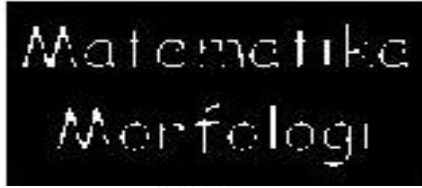

Closing

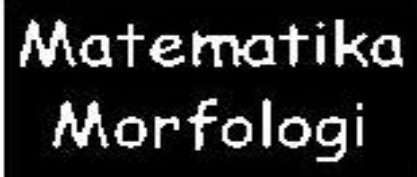

Morfologi Gradien

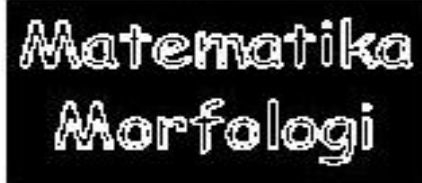

Dilasi

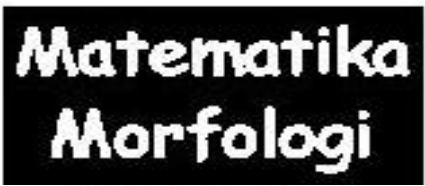

internal boundary

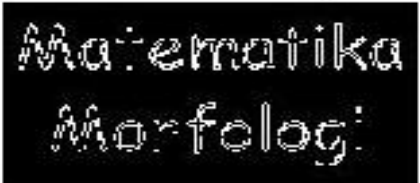

Gambar 8. Output Citra 'Matematika Morfologi'

Dari output di atas dapat terlihat bahwa hasil erosi merupakan teks yang sama namun lebih tipis. Hasil dilasi lebih mempertebal teks. Hasil opening terlihat menghilangkan objek kecil (dapat lihat pada huruf 'e', ' $r$ ', dan ' $g$ ') dan secara umum menghaluskan batas dari teks tanpa mengubah area objek secara signifikan. Efek yang dihasilkan closing sendiri yaitu mengisi lubang kecil pada objek, dan juga secara umum menghaluskan batas teks. Internal Boundary menghasil efek dimana citra yang diambil hanyalah batas teks bagian luar dan lebih tipis. Eksternal Boundary mengambil batas teks bagian dalam dan lebih tegas dari internal tegas. Morfologi Gradien mengambil batas bagian dalam dan luar teks.

Contoh lainnya untuk Erosi, Dilasi, Opening Closing, Exsternal Boundary, Internal Boundary, dan Morfologi Gradien.

A.

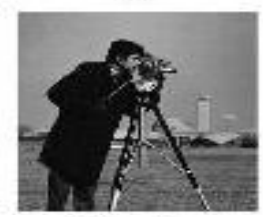

Opening

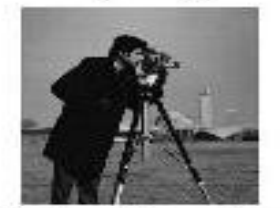

eksternal boundary

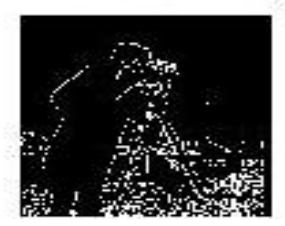

Erosi

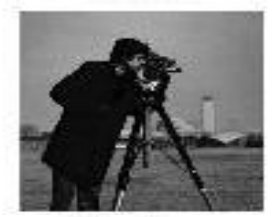

Closing

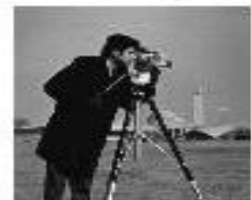

Morfologi Gradien

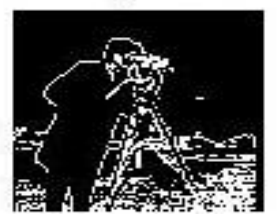

Dilasi

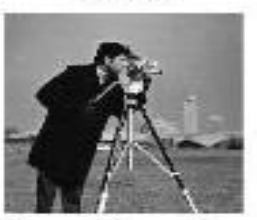

internal boundary

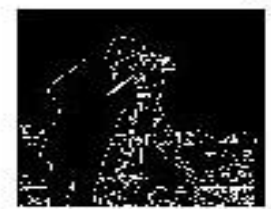

Gambar 9. Output Citra

Dari output di atas dapat terlihat bahwa hasil erosi membuat citra lebih kabur. Hasil dilasi lebih memperjelas citra sehingga citra lebih jelas. Hasil opening terlihat menghilangkan objek dan secara umum 
menghaluskan batas citra. Closing sendiri mengisi lubang kecil pada objek, dan juga secara umum menghaluskan batas teks. Internal Boundary menghasil efek dimana citra yang diambil hanyalah bagian luar citra dan lebih tipis. Eksternal Boundary mengambil batas citra bagian dalam dan lebih tegas dari internal tegas. Morfologi Gradien mengambil batas bagian dalam dan luar dari citra sehingga lebih jelas.

Sedangkan listing program untuk Filtering citra awalnya menggunakan model warna RGB yang dikonversikan ke model warna citra grayscale.

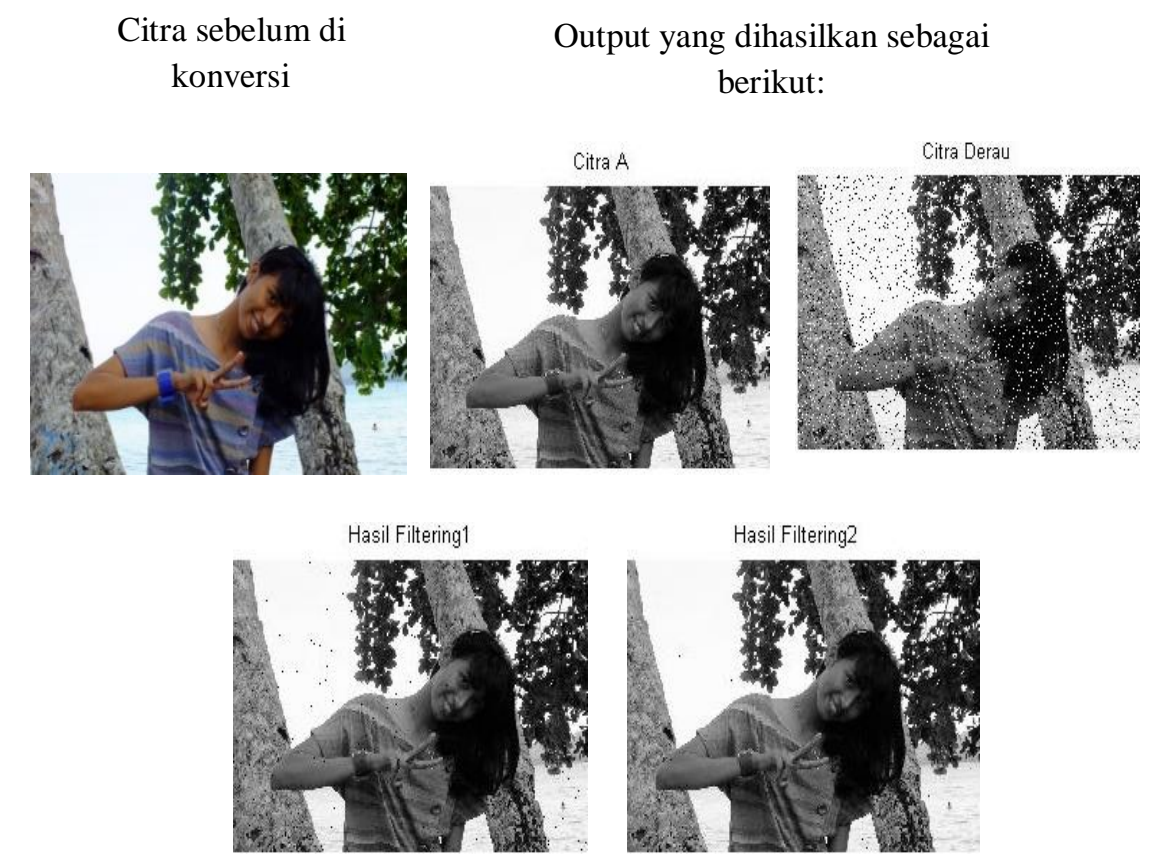

Gambar 10. Output Citra 'Eunike'

Pada output diatas citra asli merupakan citra yang menggunakan model warna RGB yang dikonversikan ke model warna citra grayscale. Dari Gambar 10 terlihat bahwa Hasil Filtering 1 yang menggunakan elemen pembentuk matriks ones (3) membuat noda pada citra derau yang sebelumnya sangat banyak terlihat lebih sedikit. Begitu pula untuk Hasil Filtering 2 yang menggunakan elemen pembentuk lain. Namun Hasil Filtering 2 terlihat lebih bersih (nodanya lebih sedikit) dibandingkan Hasil Filtering 1, sehingga dapat diambil kesimpulan bahwa hasil filtering yang baik tergantung pada elemen pembentuk yang digunakan.

\section{Kesimpulan}

Berdasarkan pembahasan pada bagian sebelumnya, maka dapat disimpulkan bahwa:

1) Operasi Himpunan dan Matematika Morfologi dapat diterapkan dalam pengolahan citra digital yaitu operasi Erosi, Dilasi, Opening, Closing, External Boundary, Internal Boundary, Morfologi Gradien, dan Filtering. Erosi membuat citra menjadi lebih tipis, Dilasi membuat citra menjadi lebih jelas atau mempertebal citra, Opening menghilangkan objek-objek kecil juga memperhalus citra, Closing menutup celah-celah yang hilang serta memperhalus citra, Internal Boundary mengambil batas luar dari sebuah citra, External Boundary mengambil batas dalam dari citra, Morfologi Gradien mengambil batas dalam dan luar dari citra, Filtering menghilangkan / mengurangi noise yang ada pada citra.

2) Elemen pembentuk yang digunakan memiliki pengaruh yang sangat besar pada hasil filtering sebab baik tidaknya hasil filtering tergantung pada elemen pembentuk yang digunakan. 


\section{Daftar Pustaka}

1. Fairhurst, M. C. Visi Komputer Untuk Sistem Robotik. Jakarta : UI Press, 1994.

2. Wolfray, R. I. Digital Image Processing. 2002.

3. Shih, F. Y. Image Processing and Mathematical Morphology. s.l. : CRC Press, 2009.

4. Foley, J. D. A. Computer Graphics: Principles and Practice in C. Second. s.l. : Addison-Wesley, Addison-Wesley. 